\title{
PROGRAM KEMITRAAN MASYARAKAT: KEGIATAN BUDIDAYA IKAN NILA DI KOLAM TERPAL UNTUK PERBAIKAN USAHA MASYARAKAT DESA SEMBULUH
}

\author{
Leni Handayani $\left(^{1)}\right.$, Sari Hayati $\oplus^{2)}$ dan Rustiana Widaryati $\oplus^{3)}$ \\ ${ }^{1,3}$ Program Studi Budidaya Perairan Universitas Darwan Ali Kampus Kuala Pembuang \\ ${ }^{2}$ Program Studi Akuntasi Universitas Darwan Ali Kampus Kuala Pembuang \\ 1,2,3 Jl. Darwan Ali, Kuala Pembuang Kabupaten Seruyan, Pos 74212 \\ E-mail : lenihandayani@unda.ac.id ${ }^{1}$, sarihayati.sh70@gmail.com ${ }^{2}$, rustianawidaryati88@gmail.com ${ }^{3)}$
}

\begin{abstract}
ABSTRAK
Tujuan kegiatan Program Kemitraan masyarakat (PKM) ini adalah peningkatan kapasitas kemampuan masyarakat Sembuluh dalam mengelola usaha budidaya ikan Nila. Kegiatan PKM ini diikuti oleh anggota kelompok budidaya yang ada di daerah mitra yang mempunyai keinginan untuk memperbaiki usaha yang telah dijalani. Permasalahan yang dihadapi adalah kurangnya wawasan dan keterampilan masyarakat tentang bagaimana budidaya ikan terutama di kolam terpal dan tentang perencanaan usaha budidaya, belum diterapkannya teknologi budidaya yang baik misalnya masalah pemberian pakan, penangan benih sebelum tebar, pencegahan penyakit ikan, kondisi kualitas perairan danau Sembuluh yang menurun sehingga dapat mempengaruhi pertumbuhan ikan dan belum ada alternatif tempat pemeliharaan ikan sedangkan permintaan terhadap ikan nila cukup tinggi. Metode yang digunakan dalam kegiatan ini adalah metode pendekatan yang melibatkan anggota kelompok budidaya ikan yang ada di daerah mitra. Pelaksanaan kegiatan dilakukan dengan metode penyuluhan, pelatihan dan praktik langsung. Hasil kegiatan PKM ini memberikan dampak positif bagi mitra karena mereka mendapatkan pengetahuan dan keterampilan tentang bagaimana budidaya ikan dan pembuatan pakan ikan serta bagaimana pemeliharaan ikan nila pada kolam terpal. Berdasarkan hasil evaluasi dari kegiatan pemeliharaan ikan pada program PKM ini memperoleh nilai kelangsungan hidup ikan nila yang dipelihara di kolam terpal selama pemeliharaan rata-rata mencapai $75,30 \%$, tingginya hasil produksi yang dihasilkan ini akan berdampak pada pendapatan petani ikan sedangkan evaluasi seluruh kegiatan PKM ini berjalan dengan baik.
\end{abstract}

Kata Kunci: Mitra, Sembuluh, Kolam Terpal, Nila

\section{PENDAHULUAN}

Ilmu pengetahuan dan teknologi sangatlah penting dan bermanfaat, apalagi untuk daerah pedesaan atau daerah pedalaman yang belum terjamah oleh ilmu pengetahuan yang luas serta kemajuan teknologi yang pesat. Pemicu kemiskinan tidak hanya dipengaruhi oleh sempitnya peluang kerja tetapi ilmu pengetahuan dan teknologi pun ikut berperan dalam meminimalisir angka kemiskinan didaerah pedesaan.

Kabupaten Seruyan merupakan salah satu Kabupaten yang memiliki perairan yang cukup banyak, baik berupa sungai, rawa danau dan laut. Salah satu danau yang cukup terkenal di kabupaten Seruyan adalah danau Sembuluh. Danau Sembuluh mempunyai potensi perikanan yang cukup tinggi dan merupakan tempat wisata yang cukup indah.

Potensi danau Sembuluh cukup tinggi untuk dikembangkan tetapi beberapa waktu ini danau ini mulai mengalami penurunan kualitas air yang berimbas pada usaha perikanan di sekitar danau.

Kondisi air mempengaruhi pertumbuhan ikan yang dipelihara di keramba jaring apung. Tingginya amoniak pada perairan merupakan salah satu faktor yang berpengaruh terhadap kesehatan dan pertumbuhan ikan
(Handayani \& Siswanto, 2019). Pemeliharaan ikan nila sudah jarang dilakukan di keramba jaring apung yang ada di perairan, hal ini karena ikan yang dipelihara pertumbuhannya lambat sehingga secara ekonomi tidak terlalu menguntungkan bagi petani ikan setempat. Pemeliharaan di keramba jaring apung dipengaruhi oleh kondisi perairan, karena media pemeliharaan yang digunakan tidak dapat dikontrol sehingga hasil produksinya pun akan terpengaruh pada kondisi ikan dan lingkungan tersebut. Menurut (Yuhana, dkk, 2017) salah satu hambatan utama dalam keberhasilan dan keberlanjutan produksi budidaya ikan di keramba jaring apung (KJA) saat ini adalah rendahnya tingkat kelangsungan hidup (SR) yang hanya berkisar antara 2040\% saja. Rendahnya tingkat kelangsungan hidup ikan ini dapat dipengaruhi oleh kondisi perairan yang rendah dan juga dapat disebabkan oleh infeksi mikroorganisme patogen. Dengan adanya faktor penghambat inilah sehingga perkembangan usaha yang dilakukan petani ikan juga terhambat perkembangannya.

Berdasarkan masalah diatas maka tim pelaksana PKM melaksanakan kegiatan untuk membantu petani ikan untuk dapat mengembangkan usahanya melalui kegiatan pemeliharaan ikan di media terkontrol yaitu 
kolam terpal. Kegiatan PKM ini dilakukan melalui kegiatan penyuluhan dan pelatihan tentang budidaya ikan nila dikolam terpal. Kegiatan pelatihan tentang budidaya ikan melalui kolam terpal pernah dilakukan di daerahdaerah lain seperti yang telah dilakukan oleh (Akhsan, dkk, 2020) yaitu memberikan pelatihan budidaya ikan air tawar dengan teknologi kolam terpal bundar yang dilaksanakan di desa Bontosunggu Kabupaten Gowa dimana hasil PKM ini menunjukkan bahwa kolam terpal dapat ditempatkan pada tempat yang terbatas seperti pekarangan rumah sehingga pengontrolan lebih mudah terutama kebersihan kolam dan hasil kelangsungan hidup ikan mencapai $70 \%$.

Pembesaran ikan nila dengan menggunakan kolam terpal sebagai wadah budidaya juga pernah dilakukan pada kegiatan PKM yang dilakukan oleh (Tomasoa, dkk, 2020) yang hasilnya menunjukkan bahwa budidaya ikan di kolam terpal mudah untuk diterapkan masyarakat dalam upaya mengembangkan usaha karena rata-rata masyarakat tidak menghadapi kendala berarti dalam membudidayakan ikan di kolam terpal dan bahkan sebagian mampu merancang dan membangun sendiri kolam terpal secara mandiri.

Kegiatan PKM yang dilaksanakan di Desa Sembuluh ini merupakan tindak lanjut dari hasil kegiatan penelitian yang dilakukan pada tahun 2019 dimana hasilnya menunjukkan bahwa kondisi perairan danau Sembuluh mengalami penurunan sehingga dianggap perlu untuk memberikan masukan kepada petani ikan yang ada di desa tersebut untuk mencari alternatif media pemeliharaan yang dapat digunakan untuk mengembangkan usaha perikanan yang telah dijalani.

Tujuan kegiatan ini adalah peningkatan kapasitas kemampuan masyarakat Sembuluh dalam mengelola usaha budidaya ikan Nila dan diharapkan dapat memberikan dampak terhadap hasil produksi ikan nila yang dilakukan melalui perbaikan usaha budidaya ikan yang dilakukan di kolam terpal.

\section{RUANG LINGKUP}

Kajian ini dibatasi pada upaya tim pelaksana PKM terhadap mitra yang ada di Desa Sembuluh Kabupaten Seruyan. materi yang diberikan pada kegiatan PKM ini pun dibatasi berdasarkan permasalahan mitra di lapangan.

Permasalahan yang dihadapi oleh mitra adalah sebagai berikut:

1. Kurangnya wawasan dan keterampilan masyarakat tentang bagaimana budidaya ikan terutama di kolam terpal dan tentang perencanaan usaha budidaya.

2. Belum diterapkannya teknologi budidaya yang baik misalnya masalah pemberian pakan, penangan benih sebelum tebar, pencegahan penyakit ikan

3. Kondisi kualitas perairan danau Sembuluh yang menurun sehingga dapat mempengaruhi pertumbuhan ikan
4. Belum ada alternatif tempat pemeliharaan ikan.

Hasil kegiatan PKM ini, diharapkan dapat memberikan pengetahuan dan keterampilan masyarakat Desa Sembuluh dalam memelihara ikan nila di kolam terpal sehingga nantinya mereka dapat melakukan kegiatan budidaya pada media terkontrol seperti kolam terpal sehingga produksi yang dihasilkan dapat meningkat dan keuntungan dapat maksimal.

\section{BAHAN DAN METODE}

Program Kemitraan Masyarakat yang dilaksanakan di Desa Sembuluh merupakan sebuah upaya yang dilakukan untuk membantu petani ikan dalam memperbaiki usaha budidaya mereka sehingga dapat meningkatkan pendapatan. Kegiatan perbaikan budidaya ini dilakukan dengan memberikan pelatihan tentang bagaimana melaksanakan budidaya dengan menggunakan kolam terpal sebagai alternatif tempat budidaya ikan dengan media terkontrol, pembuatan pakan ikan, pengendalian penyakit dengan bahan alami dan manajemen keuangan sederhana. Dalam penulisan ini disajikan bahan kajian teori dan metode pelaksanaan kegiatan program kemitraan masyarakat yang telah dilakukan.

\subsection{Budidaya Ikan di Kolam Terpal}

Budidaya ikan merupakan kegiatan memproduksi biota akuatik untuk mendapatkan suatu keuntungan (Effendi dan Mulyadi 2016). Usaha budidaya ikan berpotensi untuk meningkatkan pendapatan dan kesejahteraan pembudidaya ikan (Hermawan, dkk, 2017). Peningkatan kesejahteraan ini dapat dilakukan dengan perbaikan usaha budidaya yang dilakukan, misalnya penerapan inovasi dalam budidaya ikan yaitu dengan menggunakan kolam terpal sebagai media pemeliharaan

Kolam terpal merupakan salah satu alternatif teknologi budidaya yang dapat diterapkan pada lahan sempit, lahan minim air, atau lahan yang tanahnya porous, terutama tanah berpasir. Artinya kolam terpal merupakan salah satu solusi untuk pengembangan budidaya ikan yang dapat dilakukan pada lahan kritis dan sempit (Febriani dan Witoko, 2018).

\subsection{Metode Kegiatan}

Kegiatan dilaksanakan di Desa Sembuluh, Kecamatan Danau Sembuluh, Kabupaten Seruyan. kegiatan dilaksanakan dari bulan Juli-November 2020. Peserta yang terlibat dalam kegiatan ini berasal dari kelompok budidaya ikan yang ada di daerah mitra yang mempunyai keinginan untuk memperbaiki usaha yang telah dijalani.

Kegiatan PKM dilakukan dengan metode pendekatan. Berdasarkan permasalahan yang dihadapi oleh mitra dalam hal ini masyarakat Sembuluh dalam menjalankan usaha budidaya ikan nila (Oreochromis niloticus) agar usaha ini bisa menjadi elektif dan 
menguntungkan, maka metode yang telah dilaksanakan adalah berupa kegiatan dengan metode pendekatan partisipasi aktif secara berkelanjutan antara tim pelaksana dan mitra.

Hasil pemeliharaan ikan nila yang dilakukan oleh peserta akan dihitung presentasi kelangsungan hidupnya dengan menggunakan rumus (1) (Muchlisin, Z.A., dkk, 2016) yaitu:

$$
\mathrm{SR}=\frac{N 0-N t}{N 0} \times 100
$$

Keterangan (1)

SR : Derajat kelangsungan hidup (\%)

$\mathrm{Nt}$ : Jumlah ikan di akhir pemeliharaan (ekor)

No : Jumlah ikan pada awal pemeliharaan (ekor)

Pelaksanaan kegiatan Program Kemitraan Masyarakat (PKM) dilakukan dengan beberapa tahap seperti yang terlihat pada Gambar 1 .

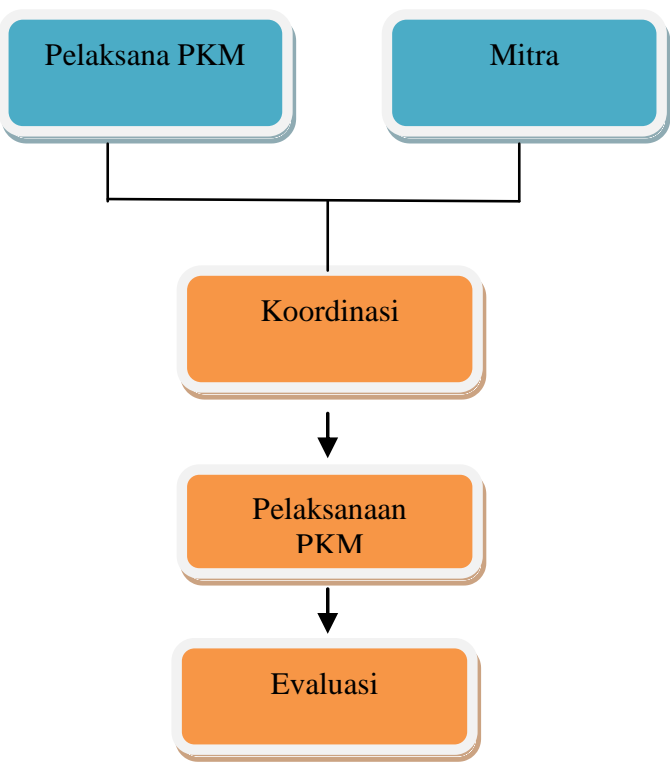

\section{Gambar 1. Tahapan Pelaksanaan Kegiatan PKM}

\section{Tahap Persiapan}

Pada tahap ini dilakukan koordinasi antara tim pelaksana dan mitra tentang teknis pelaksanaan program kerja yang akan dilakukan pada kegiatan Program Kemitraan Masyarakat. Persiapan-persiapan yang akan dilakukan antara lain persiapan yang berhubungan dengan teknis pelaksanaan program, peralatan dan bahan yang akan digunakan pada saat kegiatan dan sarana budidaya yang digunakan.

2. Tahap Pelaksanaan

Pelaksanaan program disesuaikan dengan permasalahan yang dihadapi oleh mitra di lapangan yaitu :

1) Melakukan kegiatan Penyuluhan tentang budidaya ikan Nila (Oreochromis niloticus) yang ramah lingkungan termasuk budidaya di kolam terpal

2) Memberikan penyuluhan tentang hubungan kualitas air dengan budidaya ikan.

3) Memberikan pelatihan bagaimana manajemen pemberian pakan yang sesuai dengan kebutuhan ikan nila (Oreochromis niloticus)

4) Memberikan pelatihan tentang pengendalian penyakit ikan dengan menggunakan bahan-bahan alami.

5) Memberikan pelatihan tentang Manajemen keuangan dalam usaha budidaya ikan.

6) Demo dan pendampingan tentang bagaimana membuat pakan sesuai kebutuhan ikan Nila (Oreochromis niloticus).

7) Pembuatan kolam terpal sebagai percontohan untuk masyarakat .

3. Penyuluhan Tentang Budidaya Ikan Nila (Oreochromis niloticus) yang Ramah Lingkungan.

Penyuluhan tentang tema ini melibatkan semua anggota kelompok budidaya yang ada di Desa Danau Sembuluh. Hal ini perlu disampaikan agar wawasan dan pengetahuan mitra dapat berkembang sehingga nantinya akan dapat diaplikasikan di lapangan dengan tetap menjaga lingkungan perairan karena lingkungan perairan berpengaruh (Muchlisin, 2016) langsung terhadap budidaya ikan yang akan dilakukan. Penyuluhan ini juga akan disampaikan bagaimana budidaya ikan di kolam terpal yang akan dapat dijadikan alternatif tempat pemeliharaan ikan selain keramba jaring apung.

4. Penyuluhan tentang hubungan kualitas air dengan budidaya ikan

Materi ini kami anggap perlu untuk disampaikan agar masyarakat tahu bagaimana pengaruh kualitas air terhadap budidaya ikan, karena air merupakan salah satu faktor yang mendukung keberhasilan suatu usaha budidaya. Penyuluhan ini juga akan kami sampaikan bagaimana kondisi perairan danau Sembuluh berdasarkan hasil penelitian yang Telah dilakukan pada bulan April Juli 2019 jika dilihat dari hasil analisis kualitas air berdasarkan beberapa parameter yang telah diuji. Harapkan kami nantinya masyarakat dapat mempertimbangkan kembali untuk melakukan kegiatan budidaya di kolam terjal sebagai alternatif tempat usaha budidaya ikan sehingga hasilnya dapat lebih baik dibanding keramba jaring apung dengan mengontrol kualitas air dan melakukan dengan teknik yang tepat.

Pada saat kegiatan ini, kami tampilkan hasil data pengukuran kualitas air selama penelitian tahun 2019, sehingga mereka bisa mengetahui dan dapat mempertimbangkan usaha yang sesuai dengan kondisi daerah sekarang. 
5. Pelatihan Manajemen pemberian pakan Untuk Ikan nila (Oreochromis niloticus)

Transfer ilmu pengetahuan yang dilakukan merupakan upaya untuk meningkatkan pengetahuan dan keterampilan mitra tentang bagaimana membuat formulasi pakan yang sesuai dengan kebutuhan ikan nila (Oreochromis niloticus) dengan menggunakan bahan yang mudah didapat dan harga bahan yang relatif lebih murah, karena biaya pakan merupakan biaya operasional yang besar dalam suatu usaha budidaya ikan. Selain diberi pelatihan tentang pembuatan pakan, juga diberikan pengetahuan bagaimana pemberian pakan yang sesuai dengan kebutuhan ikan nila yang akan dipelihara.

6. Pelatihan tentang Pencegahan Penyakit Ikan Dengan Menggunakan Bahan-Bahan Alami.

Pada kegiatan ini mitra akan diberikan pelatihan tentang bagaimana mencegah penyakit ikan dengan menggunakan bahan-bahan alami. Kegiatan ini dilakukan agar mengurangi penggunaan bahan kimia dalam mencegah penyakit ikan, karena penggunaan bahan kimia yang berlebih akan berpengaruh terhadap lingkungan budidaya. Kegiatan ini kita lakukan agar dapat mengurangi penggunaan bahan kimia untuk pencegahan penyakit pada ikan, sehingga dapat meminimalisir penurunan kualitas air pada media pemeliharaan.

7. Pelatihan tentang Manajemen keuangan dalam usaha budidaya ikan

Kegiatan ini perlu dilakukan karena melalui pelatihan ini mitra akan diberikan pengetahuan tentang bagaimana menganalisa usaha budidaya sehingga nantinya dapat digunakan untuk perencanaan kegiatan budidaya selanjutnya. Kegiatan ini berupa materi tentang mengatur keuangan antara lain pencatatan transaksi keuangan sampai dengan pembuatan laporan keuangan secara periodik. Dengan adanya laporan keuangan yang telah dibuat maka dapat dilakukan suatu analisis terhadap usaha yang telah dijalankan, apakah layak atau tidak usaha tersebut untuk dilanjutkan.

8. Demo dan pendampingan tentang bagaimana membuat pakan sesuai kebutuhan ikan nila (Oreochromis niloticus).

Kegiatan ini melibatkan semua anggota kelompok budidaya. Tim pengusul akan membantu dalam proses pembuatan pakan ikan sampai pakan siap digunakan. Pada kegiatan ini akan terjadi proses pendampingan dan forum diskusi antara tim pengusul dan mitra untuk memecahkan permasalahan yang dihadapi pada saat kegiatan pembuatan pakan ikan berlangsung. Kegiatan pendampingan ini bertujuan agar semua anggota kelompok budidaya dapat memahami betul-betul bagaimana pembuatan pakan ikan yang sesuai dengan kebutuhan ikan nila (Oreochromis niloticus) dan jika nanti ada masalah yang sama maka mereka sudah bisa mengatasinya.
9. Praktik Pembuatan Kolam Terpal

Praktik pembuatan kolam terpal ini, kami anggap perlu karena ada beberapa dari peserta yang belum pernah melaksanakan pembesaran dikolam terpal. Praktik ini diperlukan agar peserta mempunyai pengetahuan tentang bagaimana membuat kolam yang baik dan benar sehingga hasil produksi dapat meningkat.

\section{PEMBAHASAN}

Berdasarkan hasil pelaksanaan kegiatan Program Kemitraan Masyarakat (PKM) maka dapat diuraikan hasil kegiatan, dokumentasi dan hasil evaluasi dari kegiatan PKM dalam bentuk tabel dan diagram.

\subsection{Hasil Kegiatan PKM}

Kegiatan Program Kemitraan Masyarakat yang telah dilaksanakan memberikan dampak positif bagi mitra, dimana hasil pengukuran peningkatan pelaksana kegiatan PKM dapat dilihat pada tabel 1.

Tabel 1. Hasil Pengukuran Peningkatan Pelaksanaan Kegiatan PKM

\begin{tabular}{|l|l|}
\hline \multicolumn{1}{|c|}{ Instrumen Pengukuran } & \multicolumn{1}{c|}{ Hasil } \\
\hline $\begin{array}{l}\text { Pengetahuan tentang budidaya } \\
\text { ikan }\end{array}$ & Meningkat \\
\hline $\begin{array}{l}\text { Semangat dalam melaksanakan } \\
\text { pemeliharaan }\end{array}$ & Meningkat \\
\hline $\begin{array}{l}\text { Keterampilan dalam membuat } \\
\text { pakan dan kolam terpal }\end{array}$ & Meningkat \\
\hline
\end{tabular}

Pengukuran terhadap hasil ini diperoleh dari nilai pretest dan posttest yang dilakukan pada saat kegiatan berlangsung. Adapun nilai rata-rata hasil evaluasi yang dilakukan dapat dilihat pada Gambar 2.

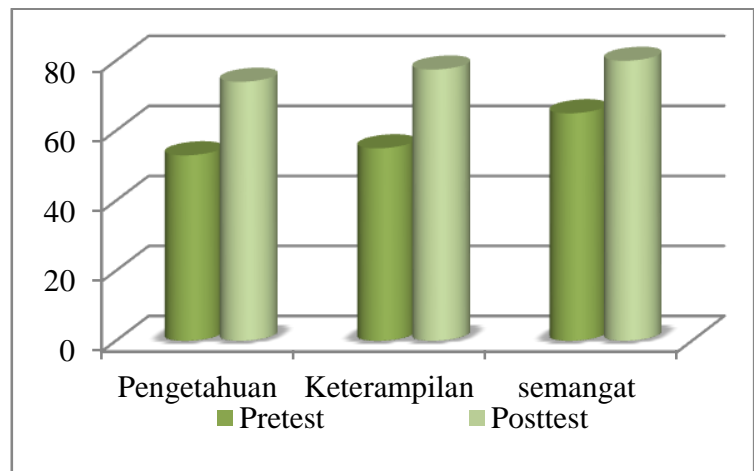

Gambar 2. Nilai rata-rata hasil tes

Berdasarkan gambar 1 terlihat bahwa nilai rata-rata pengetahuan, keterampilan dan semangat peserta terlihat meningkat dari sebelum kegiatan dilaksanakan. Peningkatan pengetahuan ini diperoleh dari hasil evaluasi yang telah dilakukan oleh tim PKM terhadap peserta kegiatan, peserta mengikuti kegiatan dengan semangat sehingga pada saat praktik, mereka dapat 
melakukan kegiatan yang diarahkan oleh tim pelaksana PKM. Peningkatan pengetahuan ini diharapkan akan mampu membantu perbaikan usaha masyarakat sehingga tujuan kegiatan budidaya dapat tercapai. Usaha budidaya berpotensi besar dalam meningkatkan pendapatan dan kesejahteraan pembudidaya ikan (Hermawan, dkk, 2017). Peningkatan pengetahuan mitra dilakukan dengan memberikan materi pada kegiatan PKM ini yang diharapkan akan menambah pengetahuan mitra tentang usaha budidaya ikan di kolam terpal. Salah satu kegiatan penyampaian materi PKM dalam bentuk penyuluhan. Penyuluhan merupakan suatu proses perubahan perilaku di kalangan masyarakat agar mereka tahu, mau dan mampu melakukan perubahan demi tercapainya peningkatan produksi, pendapatan atau keuntungan dan perbaikan kesejahteraannya (Saparini, 2017). Kegiatan pemberian materi dalam PKM yang dilaksanakan dapat dilihat dapat dilihat pada Gambar 3.

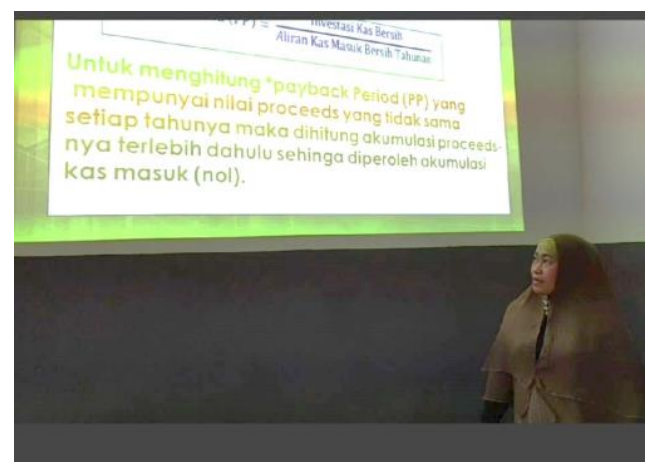

Gambar 3. Penyampaian materi PKM

Selain penyuluhan peserta juga diberikan pelatihan agar dapat meningkatkan keterampilan peserta (Harding \& Diadiyono, 2018), menyatakan bahwa pelatihan dimaksudkan untuk memberikan keterampilan yang dibutuhkan untuk melakukan pekerjaan yang dijalaninya. Pada kegiatan ini mitra tidak hanya diberikan materi pelatihan tentang usaha budidaya ikan saja, tetapi mereka juga diberikan materi praktik tentang pembuatan kolam terpal, pembuatan pakan dan penggunaan bahan alami untuk pencegahan penyakit ikan serta tentang bagaimana manajemen keuangan sehingga nantinya dapat diketahui apakah usaha yang kita lakukan dapat dilanjutkan atau tidak. Pemberian materi praktik kepada mitra dapat dilihat pada Gambar 4.

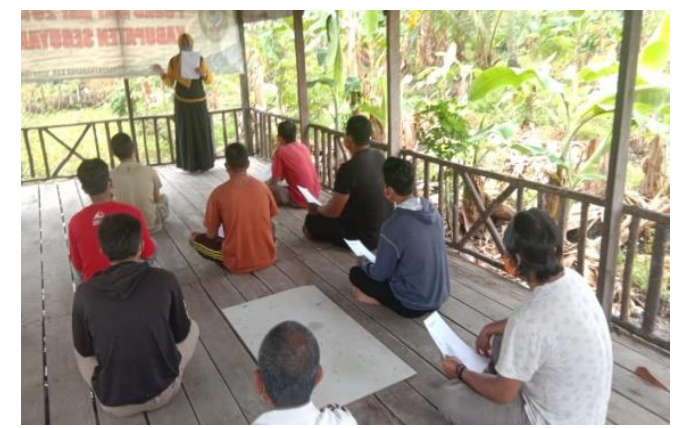

Gambar 4. Penyampaian materi Praktik
Kegiatan praktik dilakukan dengan melibatkan para peserta secara langsung sehingga diharapkan nantinya mereka akan dapat mengaplikasikan di lapangan. Pemberian materi praktik ini memberikan dampak positif bagi masyarakat, karena mereka mulai mampu untuk membuat pakan dengan bahan yang telah disiapkan oleh tim pelaksana PKM. Pemberian materi tentang pembuatan pakan ini sangat penting karena dalam suatu usaha budidaya ikan, harga pakan merupakan biaya yang terbesar dalam satu kali pemeliharaan.

Pakan merupakan faktor yang harus diperhatikan dalam upaya peningkatan produktivitas ikan yang di budi daya. Biaya pakan lebih dari $60 \%$ dari biaya total produksi ikan yang dipelihara. Kebutuhan pakan yang sangat besar dapat menimbulkan permasalahan bagi petani ikan dimana harga pakan yang semakin mahal, sehingga makin memperbesar biaya produksi (Sari \& Yulisman, 2017). Pakan dalam kegiatan budidaya harus mendapat perhatian yang besar karena biaya yang dikeluarkan untuk pakan dalam satu kali produksi sangat besar oleh karena itu pemberian pakan dalam jumlah, frekuensi dan komposisi harus tepat dan efisien agar pertumbuhan dan kelangsungan hidup ikan terjaga (Pramono \& Rahayu, 2017). Kegiatan pembuatan pakan ikan dapat dilihat pada Gambar 5.

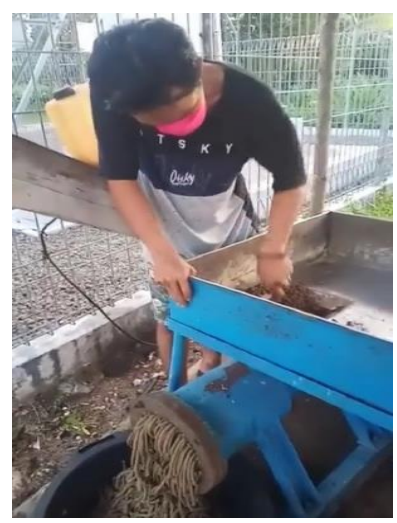

\section{Gambar 5. Pembuatan pakan ikan}

Pada kegiatan ini, tim PKM bersama mitra membuat kolam terpal sebagai contoh bagaimana pembuatan kolam dan bagaimana perlakuan yang harus dilakukan saat tebar dan bagaimana perlakuan yang harus dilakukan selama masa pemeliharaan. Materi yang diberikan dalam kegiatan PKM ini dipraktikan langsung oleh peserta kegiatan sehingga dapat memberikan keterampilan dan pengetahuan mereka dalam mempersiapkan usaha budidaya yang akan dilakukan. Perlakuan pada saat tebar juga merupakan salah satu faktor penentu dalam keberhasilan kegiatan budidaya. Menurut (Azhari, dkk, 2017) faktor yang mempengaruhi pertumbuhan ikan dalam suatu budidaya antara lain adalah ukuran benih, jenis ikan, perlakuan yang diberikan pada saat tebar dan sistem budidaya yang dilakukan. Pada kegiatan ini melibatkan semua peserta kegiatan agar peserta nantinya mampu untuk membuat 
kolam terpal secara mandiri. Pada kegiatan ini pula peserta dan tim pelaksana membuat kolam terpal sebagai percontohan, dimana pada saat kegiatan PKM ini berlangsung peserta juga memelihara ikan nila secara langsung. Salah satu kolam terpal yang sudah dibuat oleh peserta pada kegiatan program kemitraan masyarakat dapat dilihat pada Gambar 6.

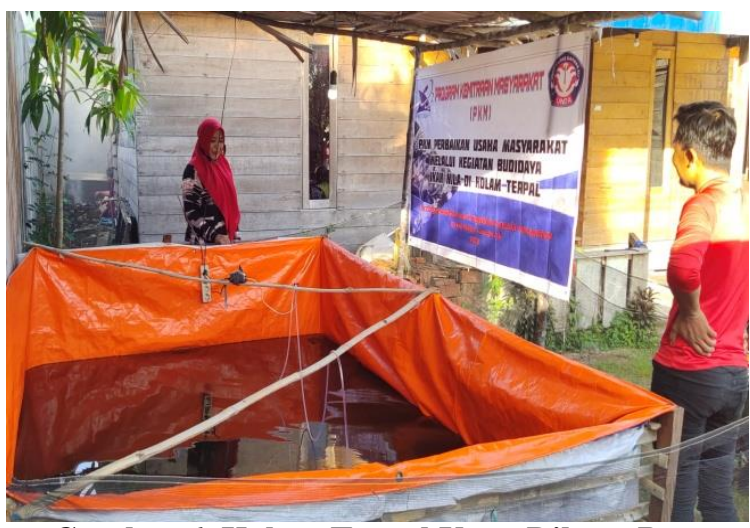

Gambar 6. Kolam Terpal Yang Dibuat Peserta

Nilai survival rate ikan nila yang dipelihara di kolam terpal selama masa pemeliharaan yang dilakukan dalam kegiatan PKM tersebut dapat dilihat pada tabel 2.

Tabel 2. Nilai Survival Rate Ikan Nila (Oreochromisniloticus) yang dipelihara Selama Pemeliharaan

\begin{tabular}{|c|c|}
\hline Kolam Terpal & Survival Rate $(\%)$ \\
\hline 1 & 72,60 \\
\hline 2 & 78,00 \\
\hline Rata-rata & 75,30 \\
\hline
\end{tabular}

Kolam terpal 1 menunjukkan nilai survival rate sebesar 72,60\% dan kolam $278,00 \%$, jika dilihat dari nilai SR nya pembesaran ikan nila yang dilakukan dapat dikatakan baik karena hasil rara-rata kelangsungan hidup ikan nila yang dipelihara pada kolam terpal mencapai $75,30 \%$, hal ini sejalan dengan pendapat (Mulyani \& Yulisman, 2014) bahwa tingkat kelangsungan $\geq 50 \%$ tergolong baik, kelangsungan hidup $30-50 \%$ sedang dan kurang dari $30 \%$ tidak baik.

Tingginya nilai SR ini menunjukkan bahwa pemeliharaan ikan di kolam terpal menunjukkan nilai positif jika dibanding dengan pemeliharaan di keramba jaring apung yang selama ini dijalankan, dimana menurut petani ikan yang ada di desa setempat hasil pemeliharaan ikan nila di keramba jaring apung pada saat panen hanya mencapai $50 \%$ bahkan kurang dari $50 \%$. Peningkatan nilai SR ini dapat dijadikan pertimbangan untuk memulai usaha budidaya ikan nila di kolam terpal, semakin tinggi hasil produksi yang dihasilkan maka akan meningkatkan pendapatan para petani ikan.

\subsection{Hasil Evaluasi Kegiatan PKM}

Berdasarkan hasil evaluasi terhadap seluruh kegiatan PKM yang telah dilaksanakan maka diperoleh beberapa data dari hasil kuesioner yang diberikan kepada peserta kegiatan. Adapun hasil tersebut adalah sebagai berikut:

1. Isi Materi yang Diberikan Mudah Dipahami

Hasil kuesioner menunjukkan bahwa isi materi yang diberikan mudah untuk dipahami, pernyataan ini didasarkan pada hasil kuesioner yang disebarkan kepada peserta. Adapun hasil yang diperoleh dapat dilihat pada Gambar 7.

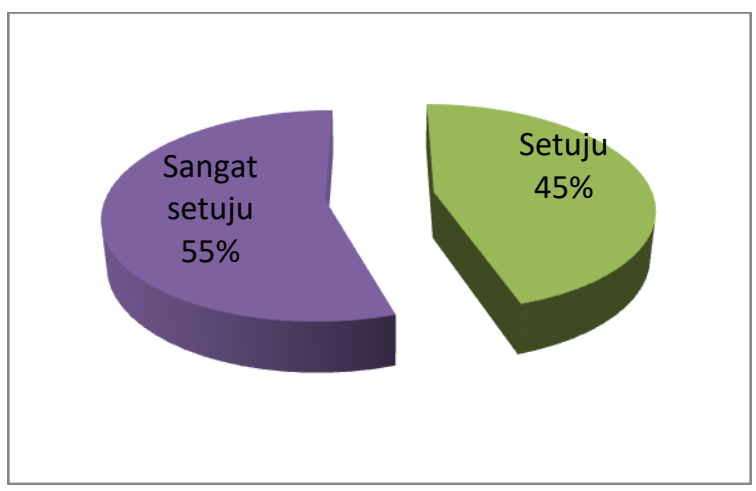

\section{Gambar 7. Hasil Kuesioner Isi Materi}

2. Materi yang Diberikan sesuai dengan Kebutuhan Di lapangan

Materi yang diberikan pada saat kegiatan disesuaikan dengan permasalahan yang dihadapi oleh mitra. Parameter ini untuk melihat apakah peserta setuju atau tidak jika materi yang diberikan sudah sesuai dengan kebutuhan mereka di lapangan sehingga permasalahan yang dihadapi petani ikan selama ini dapat memperoleh solusi alternatif media pemeliharaan ikan yang terkontrol sehingga nantinya dapat meningkatkan hasil produksi ikan yang dibudidayakan sehingga nantinya dapat memperbaiki usaha yang telah dijalani selama ini. Hasil kuesioner tentang apakah peserta setuju bahwa materi yang diberikan sudah sesuai dengan kebutuhan mereka di lapangan nantinya dapat dilihat pada Gambar 8 .

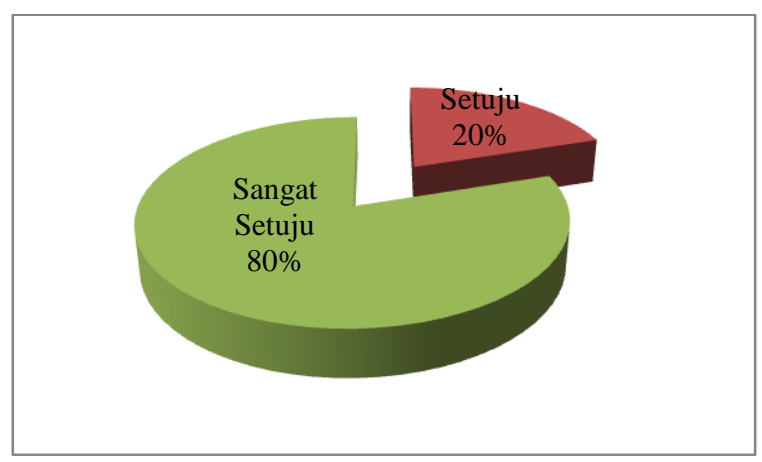

Gambar 8. Materi Sesuai dengan Kebutuhan 
Berdasarkan gambar 8 terlihat bahwa peserta setuju bahwa materi yang diberikan sudah sesuai dengan kebutuhan mereka untuk memperbaiki usaha yang telah dijalani selama ini.

3. Kesempatan Bertanya Kepada Pemateri

Hasil kuesioner untuk parameter kesempatan bertanya kepada pemateri dapat dilihat pada Gambar 9.

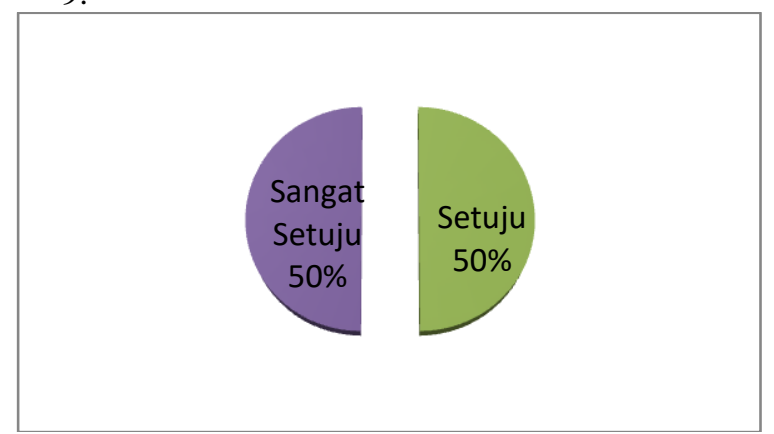

\section{Gambar 9. Hasil Kuesioner Waktu Bertanya}

Jika dilihat dari Gambar 9, maka menunjukkan bahwa peserta diberikan kesempatan yang baik untuk bertanya tentang materi yang diberikan pada saat kegiatan berlangsung.

4. Respon Pemateri terhadap Pertanyaan Peserta

Hasil kuesioner tentang respon pemateri terhadap pertanyaan yang diberikan oleh peserta dilihat dari bagaimana penyampaian pemateri dalam menanggapi pertanyaan yang diberikan, apakah jelas dan mudah dipahami oleh peserta. Hasil kuesioner dapat dilihat pada Gambar 10 .

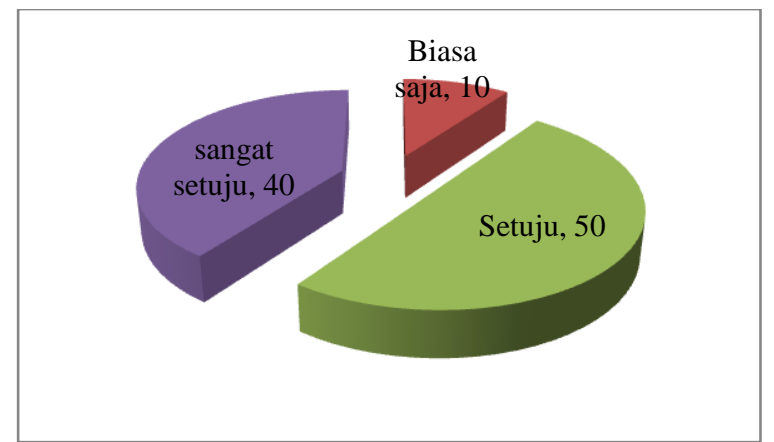

\section{Gambar 10. Hasil Kuesioner Terhadap Respon} Pemateri

Berdasarkan gambar 10 terlihat bahwa peserta menunjukkan bahwa respon pemateri terhadap pertanyaan yang diberikan oleh peserta dalam kategori baik karena $50 \%$ peserta setuju bahwa jawaban yang diberikan pemateri terhadap pertanyaan yang diberikan disampaikan dengan jelas dan mudah dipahami
5. Pemberian Contoh Dalam Praktikum Jelas dan Mudah Dipahami

Pada kegiatan evaluasi PKM, pelaksana juga menyebar kuesioner tentang bagaimana instruktur memberikan penjelasan dan memberikan contoh dalam kegiatan praktikum. Indikator ini untuk mengetahui apakan peserta setuju dengan pernyataan bahwa "Instruktur memberikan contoh yang jelas dan mudah dipahami dalam kegiatan praktikum". Hasil kuesioner dapat dilihat pada Gambar 11.

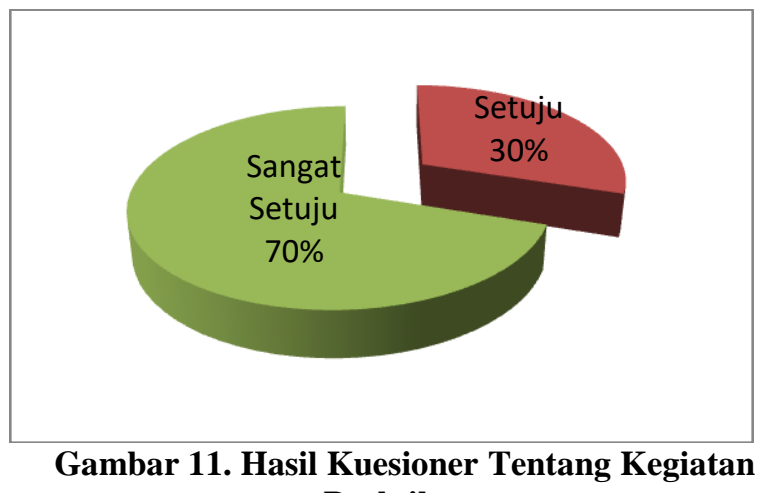
Praktikum

6. Pelayanan Pelaksana PKM Terhadap Peserta

Hasil evaluasi berdasarkan pengisian kuesioner pendapat peserta untuk melihat berapa peserta yang setuju dengan pernyataan bahwa "tim pelaksana memberikan pelayanan yang baik terhadap peserta baik tentang persiapan kegiatan, pelaksanaan kegiatan dan pendampingan dalam kegiatan praktikum sehingga peserta dapat memahami materi yang diberikan dengan baik dan nantinya dapat diaplikasikasikan di lapangan sebagai suatu usaha untuk memperbaiki hasil produksi ikan. Hasil kuesioner dapat dilihat pada Gambar 12.

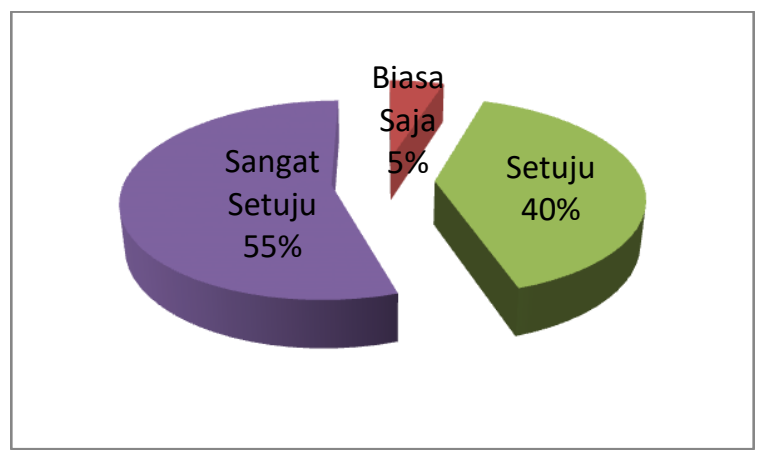

Gambar 11. Pelayanan Panitia Terhadap Peserta

\section{KESIMPULAN}

Berdasarkan dari hasil evaluasi kegiatan yang telah dilakukan, maka dapat diperoleh simpulan bahwa pelaksanaan kegiatan PKM memberikan dampak positif bagi masyarakat setempat karena mereka mendapatkan pengetahuan tentang bagaimana budidaya ikan di kolam 
terpal dan pembuatan pakan ikan. Sehingga pemeliharaan ikan nila pada kolam terpal dapat dijadikan alternatif untuk meningkatkan hasil produksi ikan sehingga nantinya dapat meningkatkan pendapatan masyarakat setempat. Kegiatan PKM secara garis besar berjalan dengan sangat baik, hal ini dilihat dari hasil evaluasi kegiatan yang menunjukkan hasil rata-rata $60 \%$ peserta sangat setuju, $37,5 \%$ setuju dan $2,5 \%$ menanggapi biasa saja terhadap materi yang disampaikan sudah sesuai dengan permasalahan yang dihadapi mitra, penyampaian materi jelas dan mudah dipahami, peserta diberikan kesempatan untuk bertanya, pemberian contoh dalam praktik jelas serta pelayanan pelaksana selama kegiatan terhadap peserta juga baik.

\section{SARAN}

Adanya kegiatan lanjutan terhadap kegiatan Program Kemitraan Masyarakat ini terutama tentang pembuatan pakan ikan yang berbasis bahan lokal sehingga pengeluaran terhadap biaya pakan dapat diminimalisir untuk meningkatkan keuntungan para petani ikan.

\section{DAFTAR PUSTAKA}

Akhsan, Said.S, \& Sofyan, A. (2020). PKM Pemberdayaan Masyarakat Melalui Budidaya Ikan Air Tawar Teknologi Kolam Terpal Bundar Di Desa Bontosunggu Kabupaten Gowa. Prosiding 4th Seminar Nasional Penelitian \& Pengabdian Kepada Masyarakat 2020, 294-299.

Azhari, A., Muchlisin, Z. A., \& Dewiyanti, I. (2017). Pengaruh Padat Penebaran Terhadap Kelangsungan Hidup Dan Pertumbuhan Benih Ikan Seurukan (Osteochilus Vittatus) Stocking Density Effect On Survival And Growth Of Seurukan (Osteochilus Vittatus) Fry. Jurnal Ilmiah Mahasiswa Kelautan Dan Perikanan Unsyiah, 2, 12-19.

Handayani, L., \& Siswanto. (2019). Korelasi Kualitas Air Terhadap Prevalensi Ektoparasit Pada Ikan Nila (Oreochromis niloticus) Yang Dipelihara Di Keramba Jaring Apung. Prosiding Seminar Nasional Perikanan Dan Penyuluhan I.

Harding., \& Diadiyono, A. L. (2018). Pelatihan dan Pengembangan SDM Sebagai Salah Satu Upaya Menjawab Tantangan MEA. Jurnal Psikologi Sains Dan Profesi, 2(2), 185-192.

Hermawan, A., Amanah, S., \& Fatchiya, A. (2017). Partisipasi Pembudidaya Ikan dalam Kelompok Usaha Akuakultur di Kabupaten Tasikmalaya, Jawa Barat. Jurnal Penyuluhan, 13(1), 1-13.

Muchlisin, Z.A., Arisa, A.A., Muhammadar, N. Fadli, I. . A. dan M. N. S.-A. (2016). Growth performance and feed utilization of keureling ( Tor tambra) fingerlings fed a formulated diet with different doses of vitamin E (alpha-tocopherol ). Archives of Polish Fisheries, 23, 47-52. https://doi.org/10.1515/aopf-2016-0005
Mulyani, \& Yulisman, F. (2014). Pertumbuhan dan Efisiensi Pakan Ikan Nila (Oreochromis niloticus) Yang Dipuasakan Secara Periodik. Jurnal Akuakultur Rawa Indonesia, 2(1), 1-12.

Pramono, M.D., \&Rahayu, E.S.F. (2017). Analisis Faktor Yang Mempengaruhi Produksi Pembenihan Ikan Lele Dumbo (Clarias gariepenus) Di Kabupaten Wonogiri. Jurnal Unimus, 343-355.

Saparini, D. (2017). Pengaruh Penyuluhan Tentang Hipertensi Terhadap Tingkat Kecukupan Kalium, Natrium, Cairan dan Tekanan darah Pada Penderita Hipertensi Peserta Prolanis Bina Sehat Di PUSKESMAS Pringsurat Kabupaten Temangguang. $\quad$ Retrieved from http://repository.unimus.ac.id/538/

Sari, I.P., \& Yulisman, M. (2017). Laju Pertumbuhan dan Efisiensi Pakan Ikan Nila (Oreochromis niloticus) Yang Dipelihara Dalam Kolam Terpal Yang Dipuasakan Secara Periodik. Akuakultur Rawa Indonesia, 5(1), 45-55.

Tomasoa, A. M., Balansa, W., \& Rieuwpassa, F. J. (2020). Pembesaran Ikan Nila Menggunakan Kolam Terpal Sebagai Wadah Budidaya Di Kampung Tariang Lama Kecamatan Kendahe kabupaten Kepulauan Sangihe. Jurnal Ilmiah Tatengkorang, 3, 39-44.

Yuhana, K. (2017). Daya antibakteri ekstrak daun kemangi (Ocimum sanctum L.) Terhadap Bakteri Streptococcus iniae Secara In Vitro. Jurnal Universitas Airlangga.

\section{UCAPAN TERIMA KASIH}

Terima kasih yang sebesar-besarnya kami ucapkan kepada pihak-pihak yang telah mendukung dan membantu kegiatan pengabdian ini, yaitu:

Kemenristekdikti yang telah memberikan pendanaan Pengabdian pada masyarakat dengan skema Program Kemitraan Masyarakat (PKM) dan Perangkat Desa serta warga Desa Sembuluh, Kecamatan Danau Sembuluh, Kabupaten Seruyan. 